\title{
A sonegação fiscal à luz do garantismo penal: o parcelamento do débito tributário e a interligação das instâncias administrativa e penal
}

Flávio Augusto Maretti Siqueira ${ }^{1}$

\begin{abstract}
Resumo
$\mathrm{O}$ artigo pretende analisar a Lei dos Crimes contra a Ordem Tributária, realizando uma interpretação sobre seus pontos mais complicados e controvertidos, passando por questões processuais e de direito material, para que, ao fim, concluamos com a exata interpretação dos dispositivos da Lei 8137/90. Nossa intenção é realizar uma argumentação acerca do modo que a lei está disposta, como ela é interpretada prestando atenção em questões importantes, tais como, o parcelamento do débito; alcançar o entendimento correto sobre a investigação administrativa da infração tributária e sua importância criminal, analisando á luz da sonegação fiscal, focado na obtenção do alcance certo das disposições.
\end{abstract}

Palavras Chave: Crimes contra a Ordem Tributária; Lei 8137/90; Teoria do Garantismo Penal.

\section{Introdução}

O Direito Penal encontra-se embebido em uma época em onde há o confronto de movimentos penais, pois duelam, de um lado, uma visão mais liberal guindada pelos ideais abolicionistas e, em outro flanco, o peso da incidência da lei mais gravosa, o movimento lei e ordem.

As idéias colidentes atravessam toda a legislação penal e isso gera uma antinomia ideológica no sistema de tutela penal, vez que há o recrudescimento da tutela penal de um lado, e o afrouxamento do outro, gerando a falta de simetria no sistema que por vezes pauta-se pela austeridade e outras pela tolerância.

No meio desse turbilhão de conflitos, os crimes tributários permanecem com penas relativamente elevadas, mas com a incidência de institutos descriminalizadores que ensejam a suspensão da punibilidade, obstando o curso da ação penal. As medidas são na verdade o reflexo do conflito entre política criminal e a arrecadação do tributo, com a utilização do Direito Penal como meio de coerção para que seja adimplida a obrigação tributária, em nítido afastamento de sua primordial função, que é a tutela de bens jurídicoconstitucionais.

1 Especialista em Direito e Processo Penal pela Universidade Estadual de Londrina. 
O equilíbrio, o qual o Direito Penal busca, está em, de um lado, salvaguardar os primordiais bens jurídicos da sociedade e, de outra banda, a mantença das garantias fundamentais do cidadão. Tal ideal se encontra esculpido nas palavras de Fábio Bittencourt da Rosa:

Atento a tais cânones, indispensável ao legislador ir extraindo da massa de valores, sob um enfoque político, a matéria do direito penal. A justa medida da normatividade estabelecerá o nível de grandeza, o grau de utilidade do sistema normativo. O direito penal exagerado revela uma presença indesejada do estado, criando a desordem pela insegurança, numa imagem draconiana, intervindo onde não deve ${ }^{2}$.

Assim, o objetivo do presente é fazer uma análise crítica dos principais institutos de Direito Penal Tributário.

\section{Princípios constitucionais tributários}

Os princípios têm a função de ser o sustentáculo do ordenamento, a base no qual se assenta todo o arcabouço normativo, sendo matrizes interpretativas a serem seguidas.

A Constituição estabeleceu verdadeiros freios limitadores à competência tributária, onde tais vetores normativos servem como imperativos que delineiam a exação estatal, por intermédio da delimitação de competências ou entabulamento de limites na execução da atividade tributária pelo Estado.

O Direito Tributário vive uma fase pentagruélica ${ }^{3}$, pois diuturnamente o Fisco desrespeita os mais comezinhos postulados constitucionais, em prol de uma autoritária arrecadação com menosprezo as garantias fundamentais dos contribuintes.

Dentro do cenário constitucional-tributário, os pilares do sistema tributário são considerados como garantias fundamentais do contribuinte, as quais são oponíveis perante

2 DA ROSA, Fábio Bittencourt. Legitimação do Ato de Criminalizar. Porto Alegre: Livraria do Advogado, 2001. p.15.

3 Pantagruélico - vem do alegre e gigantesco Pantagruel, o divertido e desbocado comilão criado por François Rabelais, escritor francês do séc. XVI. Filho de Gargantua, outro comilão lendário, Pantagruel já nasceu com um apetite descomunal, mamando diariamente o leite de 4.600 vacas. Volta e meia, ao longo dos "Horríveis e Espantosos Feitos e Proezas do Renomado Pantagruel", aparecem comilanças e bebedeiras em torno de mesas repletas de boas carnes, iguarias e vinho abundante. Por isso, usa-se uma "refeição pantagruélica" ou um "apetite pantagruélico" sempre que queremos designar qualquer exagero gastronômico. 
o fisco quando comprovado abuso ou distorção no exercício das atribuições tributárias conferidas aos entes.

Os princípios constitucionais tributários, segundo o entendimento de José Afonso da Silva ${ }^{4}$ podem incidir sobre todos os entes tributantes, como no caso dos enunciados genéricos aplicáveis de modo comum a todos os entes, ou, especificamente quando se referirem a uma dada espécie tributária; ou ainda especiais quando recaem em dadas hipóteses especiais e, ao fim, as imunidades tributárias.

Além dos princípios apontados, há de se destacar a presença dos princípios implícitos como salienta Luciano $A$ maro ${ }^{5}$, tais como, boa-fé, segurança jurídica e razoabilidade.

A lesão a principiologia tributário-constitucional gera a inexigibilidade da exação, pois contraria a justiça tributária e os pontos de sustentação do sistema constitucional, representando um ataque às garantias fundamentais do cidadão.

Como reflexo imediato, o tributo assim exigido pode ser obstado na via judicial por via de impugnação administrativa ao lançamento; por revisão de ofício pela autoridade tributária ou até mesmo através das ações impugnativas em matéria tributária.

Logicamente, por uma razão de unificação do sistema jurídico, a impugnação tributária fundada em princípios constitucionais gerará reflexos multidisciplinares, dentre eles penais, os quais serão analisados no momento oportuno.

\section{Os crimes contra a ordem tributária: um repensar da função de tutelar a ordem tributária}

A Tutela Penal da Ordem Tributária deve ser analisada sob a perspectiva crítica acerca do bem jurídico a ser tutelado, pois o Direito Penal apenas se legitima quando o bem a ser protegido encontra resguardo constitucional. Quando o legislador tenta assegurar algo que escapa a esse ideal penal-constitucional encontramos inarredável inconstitucionalidade na incriminação.

Luiz Régis Prado, dentro de uma perspectiva constitucional, leciona com propriedade:

\footnotetext{
SILVA, José Afonso da. Curso de Direito Constitucional Positivo. 18. ed. São Paulo: Malheiros, 2000. p. 693. AMARO, Luciano. Direito Tributário Brasileiro. 9. ed. São Paulo: Saraiva, 2003. p.111.
} 


\begin{abstract}
O bem jurídico pode ser conceituado como o ente (dado ou valor social) material ou imaterial haurido do contexto social, de titularidade individual ou metaindividual reputado como essencial para a coexistência e o desenvolvimento do homem e, por isso, jurídico-penalmente protegido. Além disso, deve estar sempre em compasso com o quadro axiológico contido na Constituição e com o princípio do Estado democrático e social de Direito ${ }^{6}$.
\end{abstract}

As obrigações tributárias serão legitimamente constitucionais se ela realmente perquirir proteger o bem jurídico constitucionalmente previsto, que no entender de Andreas Eisele é: "a relação de disponibilidade (no momento e dimensão material juridicamente discriminados) existente entre o sujeito passivo imediato do crime e a receita tributária que configura extensão do patrimônio público"” .

Alexandre de Moraes e Gianpaolo Smanio salientam que: "É a tutela do erário público, preservando-o de manobras fraudulentas ou de falsidades" ${ }^{8}$.

Proteger a ordem tributária como a mera atividade de arrecadação, com o fim de cobrar o débito tributário pela coerção penal é medida totalmente desraigada da finalidade precípua da função tributante, a qual é a de assegurar ativos necessários para a manutenção da máquina estatal e das políticas públicas de desenvolvimento social. É subverter o Direito Penal nas funções da Lei de Execução Fiscal, munindo o Fisco do instrumento criminal para a cobrança dos débitos fiscais.

Atuar no campo penal, com o espírito imbuído de ânimo arrecadatório gera a inversão da função penal e ataca o postulado da intervenção mínima, uma vez que, abandona-se à tutela ao fim da atividade fiscal e busca o terror para compelir o contribuinte a aderir a um parcelamento ou a quitar o débito.

\title{
3.1 Direito penal tributário e garantismo
}

O garantismo é uma teoria formulada pelo filósofo do direito, Luigi Ferrrajoli, onde o Direito deveria seguir a uma seqüência de parâmetros constitucionais mínimos que lhe confeririam legitimidade interna e externa.

A Teoria do Garantismo visa conceder racionalidade, coerência, validade justiça e razoabilidade ao sistema político-jurídico e social.

\footnotetext{
PRADO, Luiz Régis. Elementos de Direito Penal. 3. ed. São Paulo: Revista dos Tribunais, 2005. p.65. v. 1.

EISELE, Andreas. Crimes contra a Ordem Tributária. 2. ed. São Paulo: Dialética. 2002. p.48.

MORAES, Alexandre de, et al. Legislação Penal Especial. 5. ed. São Paulo: Atlas. 2002. p. 96.
} 
Luigi Ferrajoli proclama que:

Garantismo tiene tres acepciones: un derrecho penal de estricta legalidad; uma teoria jurídica de "validez" y de la efectividad" y de ser una filosofia política que impone al derecho y estado la carga de la justificación externa conforme a lós bienes y a los intereses cuya tutela y garantía constituye precisamente la finalidad de ambos ${ }^{9}$.

A Teoria propugnava o renascimento da legitimidade social do Direito e do Estado. O idealizador do garantismo objetivava, segundo Marcelo Lessa Bastos:

[...] impor ao Direito e ao Estado um fundamento de validade externo, ou seja, uma atuação que vise a garantir a tutela dos valores, bens e interesses que justificam a sua existência. É uma crítica a teorias que confundem Justiça e Direito, validade e eficácia ${ }^{10}$.

O autor supracitado sustenta ainda que:

Para o garantismo de Ferrajoli o Estado e o Direito são, em síntese, meros instrumentos a serviço de fins, valores e interesses que lhe são exteriores - porque pertencentes aos seus cidadãos. Reinterpreta-se o Contrato Social como uma grande metáfora da democracia: o Estado e o Direito foram criados pelo homem como poderes e normas que têm por finalidade proteger os próprios homens, os seus interesses vitais. Não se cuida apenas de uma democracia formal, que se permite fundar no consenso dos contratantes; mas de uma democracia substancial, fundada sobre a garantia de seus direitos ${ }^{11}$.

Então, o Direito e as instituições humanas devem ser meros objetos nas mãos da sociedade, vez que deve se prestar a tutelar a dignidade do homem e a identidade dos valores fundamentais da sociedade, os quais estão postos na Constituição.

O renascimento da legitimidade constitucional do direito e processo penal se devem a Luigi Ferrajoli por intermédio dos dez axiomas do sistema penal ${ }^{12}$ que amparam o garantismo penal, pois, por essa reconstrução, de evidente cunho jusnaturalista, lançamos

9 FERRAJOLI. Luigi. Derecho y Razón Teoría del Garantismo Penal. 5. ed. Madrid: Editorial Trotta, 2001. p. 851/853.

10 BASTOS, Marcelo Lessa. Investigação nos Crimes de Ação Penal de Iniciativa Pública: Papel do Ministério Público. Uma Abordagem à Luz do Sistema Acusatório e do Garantismo. Rio de Janeiro: Lúmen Júris, 2004. p.25.

11 Ibidem. p. 27.

12 Nulla poena sine crimine; Nullum crimen sine lege; Nulla lex (poenalis) sine necessitate; Nulla necessitas sine iniuria; Nulla iniuria sine actione; Nulla actio sine culpa; Nulla culpa sine iudicio; Nullum iudicium sine accusatione; Nulla accusatio sine probatione e Nulla probatio sine defensione. 
as bases fundamentais dos caracteres fragmentário e seletivo da tutela penal, em um processo de filtragem das condutas cuja repreensão penal seja necessária ${ }^{13}$.

O Direito Penal Tributário para ser garantista tem que observar alguns postulados basilares, onde a exação deve primar pela justiça, com respeito aos princípios constitucionais tributários e administrativos. Ainda, há de destacar o pleno respeito ao devido processo administrativo, pois as instâncias não são plenamente independentes. Além disso, há a análise conjunta dos institutos de direito tributário para se obter a configuração do fato gerador, a pertinência da alíquota e da base de cálculo, tudo isso em prol de um Direito Penal Tributário e não Tributário Penal.

\subsection{A infração penal tributária como crime continuado ou concurso formal?}

Os crimes contra a ordem tributária encontram-se previstos na Lei $8137 / 90$ e nos artigos 168-A, 334 e 337-A, todos do Código Penal.

A pertinente questão, dentre várias, que surge é a atinente à possibilidade de ocorrer concurso material ou crime continuado em hipóteses que o fato gerador é sucessivo?

O concurso material encontra-se estampado no artigo 69, Código Penal, onde o agente mediante duas condutas consegue alcançar mais de um resultado lesivo. $\mathrm{O}$ crime continuado se encontra regrado no artigo 71, Código Penal, com algumas peculiaridades, como cometimento do delito nas mesmas circunstâncias de tempo, lugar, maneira de execução e outras semelhantes.

O delito continuado apresenta uma similaridade de lugar, ou seja, entre a ocorrência de um crime e outro deve haver um liame no local das infrações penais. Ainda, o crime deve ocorrer com a utilização de meios de execução parecidos, a saber, valendo-se de mecanismos similares para efeito da prática delitiva, utilizando um plano delitivo uniforme e encadeado pela mesma forma de atuação.

Na questão atinente aos crimes contra a ordem tributária convém ressaltarmos a eventual probabilidade de crimes continuados em delitos de lapso contínuo. Entendemos que o critério considerado na jurisprudência de 30 dias entre as atividades criminosas merece atenuação, pois determinadas condutas criminosas somente poderão se dar

13 FERRAJOLI. Luigi. Op. cit. p. 93. 
obrigatoriamente em um lapso maior de 30 dias, mas que ainda se encontram entrelaçadas por um lastro lógico entre as ações criminosas.

O decurso de 30 dias preconizado com fundamento jurisprudencial, ao nosso sentir, não merece procedência, em matéria de crimes de determinada estirpe.

Guilherme de Souza Nucci ensina:

O juiz, por seu turno, não deve ficar limitado a esse posicionamento, embora possa tomá-lo como parâmetro. Imagine-se o agente que cometa vários delitos com intervalos regulares de dois meses entre eles. Merece o benefício do crime continuado, mesmo havendo mais de um mês entre os delitos, pois foi observado um ritmo preciso entre ambos ${ }^{14}$.

Andreas Eisele pontifica que:

Geralmente, os crimes contra a ordem tributária, são cometidos em relação a atividades contínuas, pois, via de regra, os fatos econômicos realizados pelo contribuinte (aferição de renda, circulação de mercadorias, pagamento de salários, etc.), sobre os quais incidem os tributos, são implementados dessa forma.

[...] os comerciantes ou industriais que realizam operações de modo contínuo, assim como qualquer empregador em face de seus funcionários, praticam fatos que reiteradamente ensejam a incidência da tributação, com a consequente obrigação do recolhimento dos valores respectivos, referentes a ICMS, IPI, IRRF, contribuição social etc.

Como cada crime se consuma na data de expiração do prazo para o recolhimento do valor correspondente ao tributo ou à contribuição social, não ocorre a figura do delito permanente, pois o momento consumativo é determinado, não se protraindo no tempo ${ }^{15}$.

Em sentido similar entende o TRF 2a Região, quanto à possibilidade de crime continuado em crime contra a ordem tributária em detrimento do concurso material:

PENAL E PROCESSO PENAL - CRIME CONTRA A ORDEM TRIBUTÁRIA - PRETENSÃO PUNITIVA - PRÁTICA DELITUOSA - ART. 1ㅇ, I, DA LEI № 8.137/90 CONTINUIDADE DELITIVA - ART. 71 DO CP - FIXAÇÃO DAS PENAS

Pretende o Ministério Público Federal a aplicação da pena contida na regra do concurso material, tendo em vista que o Apelado omitiu, nas declarações de Imposto de Renda de Pessoa Física, referentes aos exercícios de 1996 a 1999, a aquisição de inúmeros imóveis.

Não consta expressamente da peça acusatória inicial o pedido de aplicação da regra do concurso material. Somente, quando da apresentação das alegações finais, é que a Procuradora da República requereu, in fine, fosse condenado o réu

$14 \mathrm{NUCCl}$, Guilherme de Souza. Código Penal Comentado. 2. ed. São Paulo: Revista dos Tribunais, 2002. p. 268.

15 EISELE, Andreas. Op. cit. p. 82/83. 
na sanção do art. 1ำ, I, da Lei no $8.137 / 90$ c/c o art. 69 do CP (concurso homogêneo).

O Ministério Público, em suas alegações finais, requereu a aplicação do concurso material, tendo sido oportunizado, ao réu, subseqüentemente, manifestar-se a este respeito. Destarte, não há que se falar em não conhecimento desta parte da imputação, nem tampouco, em violação ao princípio da ampla defesa e do contraditório.

Diante de uma série de delitos da mesma natureza, perpetrados em seqüência, nas mesmas circunstâncias, e que se caracterizam, por ficção, um só crime, impõe-se o reconhecimento da continuidade delitiva, nos termos do art. 71 do CP.

Se, em período definido, o contribuinte reiterar a prática de fatos típicos da mesma espécie penal, admissível, consoante entendimento jurisprudencial, o crime continuado, eis que cada realização objetiva se une finalisticamente à antecedente por um vínculo de dependência.

Fixação da pena-base em 04 anos de reclusão. - Majoração da pena de multa em 300 dias-multa, tendo em vista os prejuízos causados pelo réu ao erário público, a sua situação econômica e as circunstâncias judiciais e legais. - Manutenção das penas restritivas de direitos em caráter substitutivo. Recurso parcialmente provido $^{16}$

$\mathrm{Na}$ ordem tributária devemos atentar que o recolhimento do tributo que em determinadas hipóteses é anual. Na hipótese do artigo 1으, Lei 8137/90, uma interessante hipótese surge quanto da punição do agente, pois o concurso de crimes irá influir no quantum da pena, podendo até mesmo alcançar uma elevada reprimenda quando aplicado o artigo 69, Código Penal.

Assim, por razões de política criminal e porque o artigo 71, Código Penal, não fixou prazo ou uma quantidade de tempo considerável a configurar o crime continuado, a delimitação desse lapso fica em submetida ao talante do julgador e as circunstâncias do caso concreto.

\section{Inexigibilidade de conduta diversa}

A inexigibilidade de conduta diversa é compreendida na estrutura da teoria do crime como elemento integrante da culpabilidade, dentro de um conceito analítico de crime. Como elemento da culpabilidade, pode ser descrito como o comportamento que mesmo que afronte o direito como um todo é relevado porque este não poderia demandar do

16 BRASIL. JURISPRUDÊNCIA. Origem: TRIBUNAL - SEGUNDA REGIÃO Classe: ACR - APELAÇÃO CRIMINAL.3862. Processo: 200050010085290. UF: ES Órgão Julgador: QUINTA TURMA Data da decisão: 02/03/2004 Documento: TRF200116096. DJU DATA:09/03/2004 PÁGINA: 153 JUIZA VERA LÚCIA LIMA. Disponível na internet em <http://daleth.cjf.gov.br/Jurisp/Juris.asp> Data do Acesso: 28/08/2005. 
agente qualquer outro tipo de atitude em sentido contrário face à realidade a ele apresentada.

Luís Augusto Freire Teotônio leciona: "Dessa forma, em certas circunstâncias, como dito, em que pese a coercitividade do Direito, não pode ele exigir conduta adequada do sujeito, malgrado tenha ele, agente, capacidade de culpabilidade e conhecimento do ilícito"$^{17}$.

Em tratando de crimes contra a ordem tributária, interessante é demonstrar que no ramo empresarial o mundo sofre constantes abalos advindos de crises internacionais e colapsos econômicos internos e externos, em virtude da globalização, o que traz efeitos nocivos à indústria e ao comércio, além da agressiva política tributária governamental.

Assim, muitas vezes as reviravoltas e decisões políticas de outros países apresentam seus efeitos diretamente na economia brasileira, o que causa instabilidade monetária e desvalorização dos produtos. Com isso, podemos reparar que constantemente os empresários não conseguem arcar os ônus das empresas e para mantê-la funcionando, conseguindo arcar com as obrigações trabalhistas, muitas vezes, necessário é o sacrifício do pagamento dos débitos tributários.

O Direito Penal não poderia exigir de um empresário deixar de arcar com seus pagamentos, em face de uma adversidade mercadológica ou econômica, pois o sacrifício do Fisco será sentido com menor impacto do que a falta de pagamento de um salário ao trabalhador, sendo que tal fato geraria uma reação em cadeia muito mais forte e socialmente sentida do que o inadimplemento fiscal.

As despesas com vistas a manter a empresa funcionando para assegurar seu sustento próprio, bem como aquelas com os empregados e fornecedores, revelam ser de extrema importância, não podendo sofrer qualquer reprovabilidade penal, ainda mais, porque se condenado o réu ele não poderá manter a empresa para que possa salvar a atividade empresarial e saldar sua pendência com o Fisco.

Nesse sentido, entende o TRF 2a Região:

17 TEOTÔNIO, Luís Augusto Freire.Culpabilidade - Concepções Modernas, Tendências Internacionais e Nacionais. Campinas: Minelli, 2002. p. 86. 
PENAL. APROPRIAÇÃO INDÉBITA PREVIDENCIÁRIA. RECOLHIMENTO E NÃO REPASSE DE CONTRIBUIÇÕES. INOCORRÊNCIA DO ANIMUS REM SIBI HABENDI. IMPOSSIBILIDADE REAL DE AGIR.

Como todo crime omissivo, a possibilidade real de agir deve ser clara e inerente à própria ação, sendo as dificuldades financeiras da empresa, impeditivas do repasse tributário, analisadas no próprio tipo, como pressuposto objetivo, matéria antes tratada na esfera da antijuridicidade (estado de necessidade) ou da culpabilidade (inexigibilidade de conduta diversa), havendo, como consequente que, se alguém tem justificativa idônea para o não recolhimento, inexiste a consciência e a vontade de delinqüir e, assim, o dolo e, em decorrência, o crime.

Como em Direito Penal inexiste responsabilidade objetiva, sem dolo ou culpa, não havendo forma culposa para o tipo penal em espécie, na falta do dolo não há a correspondência entre o tipo incriminador e a conduta do denunciado, por inexistência do elemento subjetivo exigido.

Desta feita, qualquer causa excludente de culpabilidade, tal como a inexigibilidade de conduta diversa pela situação econômica desfavorável da empresa, impede, não a penalização, mas o próprio processamento criminal de seus prepostos.

De outra feita, é igualmente sustentável necessitar qualquer crime tributário de um comportamento fraudulento do sujeito, sendo um fim especial de agir daquele que, tendo a consciência de que o tributo é devido, por sua livre e espontânea vontade deixa de fazer seu recolhimento, total ou parcial, burlando a fiscalização tributária.

Inexistiria, dessa forma, o dolo específico de fraudar, quando mantêm as empresas escrituração correta, e enviam informações ao Fisco, sem qualquer manipulação dolosa, e atípico seria todo ato ou fato sem a correspondente intenção de fraude. Sem tal elemento subjetivo, o que se incrimina, verdadeiramente, é um comportamento ilícito fiscal, descaracterizando a própria razão do Direito Penal moderno, que é de índole subsidiária, mínima e garantidora, só permitindo a interferência do Estado sancionador na esfera da liberdade individual quando há potencial lesivo à sociedade, ou à dignidade humana de outrem, convertendo-se, assim, qualquer prisão dessa espécie em natureza civil, por dívida, vedada constitucionalmente.

É importante ressaltar que o ônus probatório é exclusivo da acusação e não da defesa, já que a existência da conduta comissiva, precedente à omissão do recolhimento, da comprovação de uma exigibilidade de conduta diversa possível pelo sujeito, e da presença do dolo de não recolher e do dolo de fraudar, está na esfera da tipicidade, devendo a denúncia trazer a narrativa do fato com indícios do fato típico - com todos os seus elementos objetivos, subjetivos e normativos - e de sua autoria, bem como indícios de prova e peças de informação passíveis de atestar a antijuridicidade e a culpabilidade, sob pena de incidência do tratamento previsto pelo artigo 43 do Código de Processo Penal, com a sua rejeição por impossibilidade jurídica do pedido, ou ausência de justa causa. Recursos improvido ${ }^{18}$.

\title{
50 parcelamento do débito tributário e a extinção da punibilidade
}

\author{
O crédito tributário embora constituído tem sua exigibilidade suspensa em prol de
} uma situação que demonstre que o contribuinte está resistindo à pretensão fiscal. As causas

18 BRASIL. JURISPRUDÊNCIA. Origem: TRIBUNAL - SEGUNDA REGIÃO Classe: ACR - APELAÇÃO CRIMINAL 1961 Processo: 9902002463 UF: RJ Órgão Julgador: PRIMEIRA TURMA Data da decisão: 10/12/2001 Documento: TRF200105266 DJU DATA:26/09/2003 PÁGINA: 362/363 Disponível na internet em $<$ http://daleth.cjf.gov.br/Jurisp/Juris.asp> Data do Acesso: 28/08/2005. 
suspensivas do crédito tributário podem ser prévias ao início da exigibilidade daquele ou posteriores quando o crédito já está regularmente constituído.

O parcelamento no direito tributário é considerado causa suspensiva posterior à exigibilidade do crédito tributário (artigo 151, VI, CTN).

O parcelamento do tributo consiste em uma novação do débito tributário que deve ser pleiteada pelo contribuinte perante a autoridade fazendária competente.

Na senda penal, iniciou-se a discussão com o artigo 15, da Lei 8.137/90. O diploma legal mencionado foi revogado e, em substituição, veio o artigo 34 da Lei 9.249/95, que previa a decretação da extinção da punibilidade do réu, caso este realizasse o pagamento do débito para com o Fisco antes do recebimento da denúncia. Uma questão pertinente apareceu na hipótese da integral quitação do tributo ou na existência de parcelamento da dívida tributária, mas sem o amortizamento da pendência.

A Lei Penal Tributária apontava o termo "promover o pagamento", sendo certo que tal expressão gerou celeuma e diversas interpretações acerca do exato sentido da expressão.

O ato de promover o pagamento é uma expressão de conteúdo não delimitado, pois promover é dar início a, ensejar, então, não há de ser entendido como o integral adimplemento do tributo. Ainda mais, porque esvaziaria de razão o contribuinte firmar o parcelamento com o Fisco, uma vez que não obteria qualquer reflexo penal com tal acordo e ficaria em evidente desigualdade quando analisada sua conduta juntamente com a do contribuinte que quitou o débito do mesmo modo, mas de uma vez só.

Juary C. Silva aponta os aspectos benéficos do parcelamento:

No tema do pagamento e do efeito extintivo da punibilidade impende, por último, analisar o problema do pagamento parcelado do débito, freqüentemente autorizado pelo Fisco, mediante permissivo legal expresso, com o fito de agilizar a arrecadação, por isso que o parcelamento é benéfico para os contribuintes, bem como antecipa de certo modo o ingresso dos débitos nos cofres públicos, depende dos percalços de processos judiciais ${ }^{19}$.

Fernando Tadeu Cabral Teixeira entendeu que:

A conclusão de que o parcelamento do débito tributário realizado antes do recebimento da denúncia é causa extintiva da punibilidade não decorre, assim, de uma interpretação puramente gramatical, mas de uma interpretação sistemática

19 SILVA, Juary C. Elementos de Direito Penal Tributário. São Paulo: Saraiva, 1998. p. 162. 
na qual são levados em conta os princípios da intervenção mínima ou da subsidiariedade do direito penal, da proibição da analogia legis in malam partem e do princípio da isonomia, este com assento Constitucional. Ora, com a devida vênia das doutas opiniões em contrário, resta evidente que a intenção do legislador ao utilizar o verbo promover o pagamento abrange, também, o ato do contribuinte que parcela o crédito fazendário apurado, pois não fosse essa a intenção, o legislador seria enfático e teria utilizado o verbo efetuar. E, se neste caso não o fez, não foi por mero acaso, mas por opção legislativa. Quando o legislador pretendeu que somente o pagamento integral do crédito tributário fosse causa extintiva da punibilidade o fez expressamente, como ocorre na hipótese prevista pelo parágrafo 3o do artigo 15, da Lei 9.964/2000, que institui o Programa de Recuperação Fiscal REFIS. Por outro lado, nos casos em que o agente parcela o crédito fazendário ou ingressa no REFIS, ocorre a suspensão da pretensão punitiva estatal, nos termos do caput e inciso II, do artigo 15 , da Lei $9.964 / 2000^{20}$.

Então, surgem entendimentos que seria extinta a punibilidade caso isso ocorresse, como lembra Rodrigo Fernando de Freitas Lopes:

[...] a concessão do parcelamento antes do recebimento da denúncia independentemente do pagamento de todas as parcelas implica a necessária extinção da punibilidade em razão da novação da dívida ocorrida, passando o problema a ser de natureza civil e não mais da esfera penal ${ }^{21}$.

Contudo, podemos notar que a norma mencionava o termo pagamento, e havia entendimento de que esse deve ser entendido na sua acepção integral, ou seja, a quitação completa da pendência e não a mera novação consistente em uma promessa de pagamento fracionado na data futura.

André Nabarrete Neto apresentava:

Sob as premissas de que o pagamento do tributo ou contribuição deve ser integral e de que deve ocorrer antes do recebimento da denúncia, nenhuma dúvida subsiste de que o mero pagamento temporal do débito vencido não extingue a punibilidade, Parece cristalino que a promessa de pagamento futuro não se equipara ao pagamento efetivo, nem tampouco à realização parcial deste $e^{22}$.

Houve uma sucessiva evolução nas leis que cuidaram da matéria dos reflexos penais do parcelamento tributário, passando pelo REFIS, a qual culminou no artigo 9ㅇ, Lei

20 TEIXEIRA, Fernando Tadeu Cabral. O parcelamento do débito tributário como causa extintiva d punibilidade artigo 34, da Lei 9.249/95. Disponível na internet:<http://www.ibccrim.org.br>, 11.04.2003 Data do Acesso: 29/08/05.

21 LOPES, Rodrigo Fernando de Freitas. Crime de Sonegação Fiscal: A crise do Estado como causa de exclusão da culpabilidade. Curitiba: Juruá, 2002. p. 154.

22 NABARRETE NETO, André. Extinção da Punibilidade nos Crimes contra a Ordem Tributária. RBCcrim. Ano 50. № 17 - janeiro/março. São Paulo: RT. 1997. p. 176. 
10.684/03. Muito embora haja vedação legal ao alcance da pessoa física adentrar ao parcelamento, a exegese em sentido contrário pode ser obtida por uma análise da analogia in bonan partem; princípio da capacidade contributiva e da própria isonomia substancial.

Os parcelamentos firmados antes da Lei $10.683 / 03$ são entendidos como prejudicial ao mérito da ação penal, onde o curso daquela encontra obstaculizado pela ocorrência de questão que afeta diretamente o mérito da área penal. Ainda, há de se consignar que o contribuinte acaso preencha os requisitos do PAES poderá adentrar no novel programa pelo valor remanescente do débito, o que configuraria uma novação no débito tributário.

Verificamos que a nova lei nada fala acerca de limitação temporal para que se entre no PAES, pois faz menção a suspensão da pretensão punitiva e tal é mantido independentemente do momento, antes ou depois do recebimento da denúncia, levando posteriormente a extinção da punibilidade.

Heloísa Estellita leciona:

[...] uma leitura apressada, feita sob a ótica da disciplina do antigo Refis, do novo §2ㅇ do artigo 9o poderia levar à crença de se tratar de norma que faz referência ao momento final do parcelamento,ou seja,que o final do parcelamento, implicando em pagamento, levaria à extinção da punibilidade. Sim, o entendimento está correto, mas o dispositivo diz mais que isto. Em nosso entender, o dispositivo pode perfeitamente ser interpretado de forma a permitir que sempre que houver pagamento independentemente de ser o momento final do parcelamento, extinta estará a punibilidade e, agora, sem limite temporal, isto é, sem que o recebimento da denúncia inviabilize o efeito jurídico-penal do pagamento integral do tributo ${ }^{23}$.

Outra questão pertinente quanto à extinção da punibilidade reside no alcance dela, uma vez que poderia ela alcançar o co - autor?

A hipótese do alcance da medida é importante de ser analisada, pois, imaginemos o caso em que um terceiro emite notas falsas para glosa do imposto de renda de terceiros que as usaria para esse objetivo, logicamente, teriam praticado o delito do artigo 10, I e o IV. Caso o contribuinte arque com o débito quitando-o, se beneficiaria o terceiro?

O artigo 30, Código Penal prevê que as circunstâncias subjetivas não se comunicam, salvo quando elementares.

Então, insurgem duas correntes, uma sustentando a não comunicabilidade pelo pagamento consistir em circunstância subjetiva e que a conduta do agente consistia em

23 ESTELLITA, Heloísa. Pagamento e Parcelamento Nos Crimes Tributários: A nova disciplina da Lei 10.684/03. Boletim do IBCCRIM, Setembro. São Paulo: Revista dos Tribunais, 2003. 
elaborar, distribuir, fornecer e emitir documento com o fim de terceiro usar para sonegar tributos. A conduta encerra o falsum e independentemente da destinação oferecida à nota, sua ação findou sua participação no crime. Outra corrente entende que a circunstância, apesar de subjetiva comunica-se por ser elementar do crime e que este abrange o consubstanciado no artigo 580, Código de Processo Penal e no elencado na Súmula 17 do STJ, a qual concordamos.

\section{A representação fiscal para fins penais: a interligação das instâncias penal e} administrativa

O Ministério Público, por algumas vezes, vem atuando de forma precipitada e afoita na apuração dos ilícitos penais tributários, pois não obtém prova satisfatória a preencher os requisitos de indícios de autoria e materialidade, deixando ausente à justa causa.

Os crimes contra a ordem tributária são mais eficazmente apurados pela via do procedimento administrativo, uma vez que a reunião de elementos probatórios é conseguida por meio do procedimento administrativo fiscal realizado pelo ente tributante, onde pode ser alcançada a comprovação de ilícito tributário e também de ilícito penal, aproveitando-se ainda da dispensabilidade do Inquérito Policial.

O procedimento administrativo tributário tem recurso administrativo, o qual permite a rediscussão da causa em outros graus administrativos que poderão atestar a inexigibilidade do tributo e a conseqüente ausência de crime contra a ordem tributária.

O artigo 83, da Lei 9.430/96 instituiu que: "A representação fiscal para fins penais relativa aos crimes contra a ordem tributária definidos nos artigos $1^{\circ}$ e e $2^{\circ}$ da Lei $\mathrm{n} 08.137$, de 27 de dezembro de 1990, será encaminhada ao Ministério Público depois de proferida a decisão final, na esfera administrativa, sobre a exigência fiscal do crédito tributário correspondente".

A representação fiscal para fins penais deve receber seu contorno processual penal, para que possa ser ofertado o seu real tratamento, uma vez que há uma celeuma acerca de sua natureza jurídica, pois uns entendem sê-la condição de procedibilidade; outros condição objetiva de punibilidade e, ao fim, elemento integrante do tipo penal tributário.

Hermann Lott assinala que: 
A despeito das divergências, temos que o dispositivo se harmoniza com a nova natureza conferida pela lei $8.137 / 90$ ao delito tributário. Com efeito, se o delito se consuma com o resultado; se o resultado consiste na supressão ou redução do tributo e tal efeito comporta discussão na esfera administrativa tendente a uma decisão sobre a própria exigência do crédito tributário, ou, em última análise, sobre a própria existência da obrigação tributária, principal ou acessória, cujo descumprimento importa na prática do delito, por óbvio que antes da decisão administrativa é grande o risco de, em caso de denúncia, estar se processando o cidadão por um fato inexistente, ou seja, por uma conduta, comissiva ou omissíva, da qual ele não estava obrigado a se abster, razão por que o legislador preferiu estabelecer uma condição específica de procedibilidade para a ação penal

Assentada a pertinência lógica da exigência legal, cumpre salientar que, a nosso sentir, equivocam-se os autores sobre qual a verdadeira condição de procedibilidade criada pela lei. Parece-nos claro, entretanto, que o que de fato importa é a verificação final, na seara administrativa, da supressão ou redução do tributo e não propriamente o encaminhamento da representação, pela autoridade administrativa, ao Ministério Público.

A reforçar o argumento, pensamos que à autoridade administrativa, e disto ninguém a de discordar, não é dado, após a decisão final sobre a exigência fiscal do crédito tributário, fazer juízo de oportunidade e/ou conveniência de encaminhamento da representação ao Ministério Público (vide Dec. 2.730/98).E, se assim o é, a denominada "representação" não passa de obrigatório encaminhamento de notitia criminis, posto que a representação penal tem por essência a disponibilidade do direito de representar, inclusive sujeito a decadência.Ora, se consiste em verdadeiro dever funcional o mencionado encaminhamento, a omissão, intencional ou não, da autoridade administrativa não impedirá a atuação do MP, que poderá requisitar (na presença da verdadeira condição de procedibilidade, qual seja, a verificação da exigência), os documentos referentes à conclusão do procedimento administrativo e, conforme o caso, promover a responsabilidade penal da autoridade fazendária por prevaricação.

A condição específica de procedibilidade é, pois, a decisão final, na esfera administrativa, que conclui pela exigência fiscal do crédito tributário, e não a 'representação' da autoridade administrativa. Evidente que em todo caso de preclusão da instância administrativa também estará satisfeita a condição de procedibilidade $^{24}$.

A despeito do explanado, podemos verificar que a representação fiscal para fins penais não é uma condicionante ao exercício ministerial do direito de ação, uma vez que a ação penal por crime de sonegação fiscal é pública e incondicionada à luz da Súmula 609, STF.

O Ministério Público não se encontra vinculado para a provocação da instância penal tributária, desde que concorrentes os requisitos do artigo 41, Código de Processo Penal, pois o oferecimento da denúncia é meio de se obstaculizar o curso da prescrição penal, afastando a impunidade, ainda mais com a previsão do artigo $39 \S 5$, CPP.

24 LOTT, Herman. Crimes contra a ordem tributária. Jus Navigandi, Teresina, a. 6, n. 58, ago. 2002. Disponível na internet em: <http://jus2.uol.com.br/doutrina/texto.asp?id=3054>. Acesso em: 01/09/2005. 


\section{Outro não é o sentimento manifestado pelo Encontro Nacional dos Promotores de} Justiça que atuam na área de Crimes contra a Ordem Tributária (ENCNAC), através dos enunciados 7 a 10, em carta de conclusões elaborada em Curitiba em 1997:

Os Promotores de Justiça da Bahia, Goiás, Ceará, Maranhão, Mato Grosso, Minas Gerais, Pará, Paraíba, Paraná, Pernambuco, Piauí, Rio de Janeiro, Rio Grande do Sul, Roraima, Santa Catarina e São Paulo, que atuam na área de combate aos crimes contra a ordem tributária, reunidos nos dias 04 e 05 de abril de 1997, na sede da Procuradoria Geral de Justiça do Ministério Público do Estado do Paraná, na cidade de Curitiba, após discussões e debates sobre os seguintes temas:

[...]

7.) são inconstitucionais os termos do art. 83, da Lei Federal no 9430/96, pois ofendem os princípios da separação dos poderes (art. 2으, da Constituição da República), da inafastabilidade da apreciação do poder Judiciário (art. 5ำ XXXV, da Constituição da República), da titularidade exclusiva de ação penal pública pelo Ministério Público e de sua autonomia funcional (art. 127, 'caput' e $\S 10$ e 2으, art. 129, I, da Constituição da República), da igualdade (art. 5o , 'caput', da Constituição da República), da moralidade administrativa (art. 37, 'caput', da Constituição da República), e dos objetivos fundamentais da República Federativa do Brasil (art. 1으, II e art. 3], I a IV, da Constituição da República);

8.) em, eventualmente, não prevalecendo o entendimento da inconstitucionalidade do art. 83, da Lei Federal no 9430/96, sua aplicação restringir-se-á ao âmbito da Administração Federal, em razão da autonomia legislativa dos Estados e Municípios em matéria tributária;

9.) do mesmo modo, em não prevalecendo o entendimento da citada inconstitucionalidade, impõe-se reconhecer que a regra do art. 83, da Lei Federal no 9430/96, não criou condição de procedibilidade, devendo o termo 'representação' nela contido, ser entendido apenas como notitia criminis;

10.) da mesma sorte, a regra do art. 83, da Lei Federal $n=9430 / 96$, deve ser interpretada no sentido de que a remessa, pelos agentes fazendários, das informações sobre crimes contra a ordem tributária é obrigatória após o transito em julgado na esfera administrativa, nada impedindo a remessa facultativa antes desta data, por ato voluntário da autoridade fazendária ou em atendimento à requisição do Ministério Público ${ }^{25}$.

Contudo, há de se notar que, por medida de justiça, não se pode olvidar que para que ocorra a prolação do édito condenatório há de se ter à delimitação da ocorrência efetiva de crime tributário.

Então, surge a corrente que defende sê-la condição objetiva de punibilidade, uma vez que a decisão administrativa tributária que confirma a exação, por ser um acontecimento futuro e incerto, se amolda ao instituto supramencionado.

25 Conclusões do Encontro Nacional dos Promotores de Justiça que atuam na área de Crimes contra a ordem mtributária. Disponível na internet em: <http://www.mp.mg.gov.br/caoet>. Data do acesso: 08/10/05. 
Noutro giro, com amparo em uma contextualização geral do Direito, ressaltamos com amparo na teoria da tipicidade conglobante que se o Direito Tributário não considerar a conduta como ilícita, o Direito Penal não pode, de modo antinômico, considerá-la como crime.

Caso o fato não constitua ilícito tributário e o agente se postou de acordo com as regras estipuladas pelo Fisco, o atuar foi no exercício regular de direito, o que segundo a teoria de Zaffaroni excluí a tipicidade da conduta e gera a atipia do fato, passível de ser declarada por meio de Habeas Corpus.

Pela perspectiva da Imputação Objetiva temos que, se o agente não gerou um risco proibido ao Fisco na Sonegação Fiscal, descabe eventual atribuição de responsabilidade penal pelo fato.

O risco é a probabilidade de ocorrência do perigo de lesão a determinado bem jurídico, sendo a manifestação da possibilidade da sobrevinda de dano ao objeto tutelado pelo direito. A concretização de uma situação, na qual é visível a potencial ocorrência da ameaça à integridade do bem em que incide a tutela penal é o chamado risco.

André Luís Callegari aponta com base em Claus Roxin que a imputação objetiva interliga-se ao princípio do risco sendo que:

Um resultado causado pelo sujeito que atua somente deve ser imputado ao causante como sua obra e somente cumpre o tipo objetivo quando: 1) o comportamento do autor criou um risco não permitido para o objeto da ação; 2) quando o risco se realizou no resultado concreto e 3) quando o resultado se encontrava dentro do alcance do tipo ${ }^{26}$.

O risco proibido nos crimes contra a ordem tributária depende da analise do comportamento de provocar um risco proibido, ou seja, suplantar os limiares que escapam a Execução Fiscal por parte do Estado.

Antônio Luís Chaves Camargo ao analisar essa teoria leciona:

A imputação objetiva tem um vínculo específico com a ação humana, uma vez que há necessidade da criação de um risco juridicamente desvalorado e estes devem ser encontrados concretamente no resultado. Há na ação humana uma finalidade consciente e objetiva que é a possibilidade de direção e domínio da vontade com relação ao risco juridicamente relevante para o Direito Penal. Assim, não se tratava de uma visão autoritária da relação de causalidade que atribui ao agente as conseqüências de seu ato, para depois deduzir a relevância do resultado para o

26 CALLEGARI, André Luís. Imputação Objetiva no Direito Penal. Revista Brasileira de Ciências Criminai IBCCrim. RT. Ano 8, no 30, abril/junho. São Paulo. 2000, p. 67. 
Direito Penal; ao contrário, na análise da ação há de examinar-se que, se o ordenamento jurídico não proíbe determinada conduta é porque esta não se constitui num risco de lesão ao bem jurídico ${ }^{27}$.

Julio Fabbrini Mirabete explica que: “questão prejudicial é toda questão jurídica de direito penal ou extrapenal que verse elemento integrante do crime e cuja solução, escapando à competência do juiz criminal e provocando a suspensão da ação penal, deve preceder a decisão da questão principal”28.

Aloísio Firmo Guimarães da Silva salienta, com forte embasamento, que o questionamento na via administrativa configura uma elementar do próprio tipo penal:

As condições objetivas de punibilidade, como acontecimentos externos vinculados à imposição concreta da pena, (vi) concebidas pelo legislador por razões de política criminal e fundamentadas no conceito doutrinário de risco assumido, (vii) além de não integrarem a estrutura do tipo de injusto e da culpabilidade, também não estão cobertas pelo dolo ou culpa do agente. Pois bem, partido-se dessa concepção doutrinária, torna-se inconcebível aceitar a conclusão do processo administrativofiscal como condição objetiva de punibilidade, de forma a coarctar o órgão ministerial de oferecer a peça acusatória respectiva.

De fato, se a efetiva exigibilidade do tributo espelhada no auto de infração ainda encontra-se sob o crivo da administração tributária, face à pendência de recurso interposto pelo contribuinte, é possível que, em determinada situação específica, qual seja, quando houver a impugnação do nascimento do fato gerador da obrigação tributária, o resultado da decisão administrativa definitiva afete o tipo de injusto, vinculando, por conseguinte, o teor da sentença penal no sentido da nãocaracterização do ilícito penal tributário.

Nessa situação particular, em que o conteúdo da decisão definitiva da instância administrativa possui aptidão para esvaziar o conteúdo do tipo de injusto, caso seja reconhecida a pretensão do contribuinte, forçoso concluir que ela não pode ser tida como condição objetiva de punibilidade, mas sim como elemento integrante do tipo penal tributário, uma vez que estará ausente a efetiva supressão ou redução do tributo estampada no auto de infração.

Vê-se, portanto, que, malgrado se reconheça a autonomia entre as esferas penal e administrativa, em certas circunstâncias especiais, (viii) há uma relação recíproca de interferências, que poderá conduzir a uma unidade do ilícito, justificando não o impedimento ao exercício da ação penal, mas sim a aplicação da disciplina das questões prejudiciais heterogêneas (arts. 92/93 do CPP), suspendendo-se o curso do processo penal ${ }^{29}$.

27 CAMARGO, Antônio Luís Chaves de. Imputação Objetiva e Direito Penal Brasileiro. São Paulo: Livraria Cultural. 2001, p.72.

28 MIRABETE, Julio Fabbrini. Processo Penal. 16. ed. São Paulo: Atlas, 2004. p. 217.

29 SILVA, Aloísio Firmo Guimarães da. Crimes tributários e condição objetiva de punibilidade. Jus Navigandi, Teresina, v. 8, n. 183, 5 jan. 2004. Disponível em: <http://jus2.uol.com.br/doutrina/texto.asp?id=4636>. Acesso em: 01 set. 2005. 
Com o fim de evitar o afã acusatório, de bom alvitre, o Ministério Público aguardar a decisão administrativa para que seja delineadas autoria e materialidade, vez que

daí apurado o quanto do ilícito penal de modo definitivo será possível fazer o enquadramento penal da conduta, ou seja, arquivando ou denunciando.

Andreas Eisele, contudo, entende que:

O titular da ação penal correspondente a um crime contra a ordem tributária (órgão do Ministério Público), pode tomar conhecimento da existência de indícios de autoria e materialidade e autoria do fato, anteriormente à constituição definitiva do crédito tributário referente à obrigação tributária daquele decorrente. Como a decisão a ser proferida para a solução de tais questões pode acarretar reflexos na esfera criminal (pela constatação da inexistência da relação jurídica de natureza obrigacional e de cunho tributário), consistentes no reconhecimento da não existência, na situação fática, de uma das elementares do tipo penal (o tributo), é necessário identificar quais as hipóteses em que tais reflexos podem incidir sobre o âmbito criminal do fato e a natureza jurídica dessa incidência.

Para identificar as hipóteses nas quais os reflexos de eventual decisão administrativa (ou judicial) que anular o lançamento do crédito tributário, possa atingir o fato típico penal relacionado com o fato imponível descrito na hipótese de incidência da norma tributária, é necessário especificar a configuração do fato típico penal e delimitar os efeitos da referida decisão (administrativa e judicial).

O núcleo dos tipos (penais em branco) que descrevem os crimes contra a ordem tributária de conteúdo material (que apenas se consumam com a ocorrência do resultado consistente na evasão tributária), é estruturado mediante a indicação de condutas que implementem a irregular inadimplência da prestação de uma obrigação tributária (de forma fraudulenta ou não), independentemente da eventual constituição posterior do crédito correspondente a essa relação jurídica (eis que o crime se consuma com a ocorrência do dano, e a atividade da vítima imediata na busca de sua reparação é uma hipótese que pressupõe a existência dessa conseqüência do fato).

Dessa forma, a existência da obrigação tributária é um pressuposto para a tipicidade da conduta (pois a elementar tributo é o objeto de sua prestação), mas a existência do crédito tributário com aquela relacionado é irrelevante no âmbito da tipicidade penal do fato.

Portanto, com a eventual existência do crédito tributário é irrelevante na esfera criminal, a decisão administrativa (ou mesmo judicial) que reconhecer a nulidade do lançamento do crédito sem declarar a inexistência da obrigação tributaria, não produz efeitos em relação à apuração da ocorrência do crime respectivo.

Como nada impede a propositura de ação penal em relação a fato típico cujo conteúdo configure evasão tributária se não estiver constituído o crédito tributário correspondente, em regra não há necessidade de se aguardar o término do procedimento administrativo de seu lançamento para o início do processo penal (ou eventual instauração de inquérito policial) referente ao crime contra a ordem tributária com aquele relacionado.

Como matéria objeto da decisão no procedimento administrativo (ou processo judicial) pode ser um pressuposto para o reconhecimento da própria tipicidade do fato na esfera penal (quando versar sobre a própria obrigação tributária e não apenas sobre o crédito correspondente), consiste em uma questão prejudicial ao reconhecimento do crime.

Por esse motivo, sempre que houver impugnação, por parte do suposto autor de crime contra a ordem tributária, ao procedimento de lançamento do crédito 
referente à obrigação tributária decorrente do substrato fático respectivo, é recomendável que o Ministério Público avalie o conteúdo da referida impugnação antes de decidir acerca da propositura da ação penal.

A natureza da justa causa é similar à da questão prejudicial regulamentada no art. 93, CPP (em face do conteúdo fático de ambos os institutos), diferindo desta apenas no que se refere ao momento de verificação (anteriormente ou posteriormente ao início do processo penal).

Por esse motivo, não possui natureza de condição de procedibilidade, pois a análise desse instituto tem como pressuposto a verificação da ocorrência de um crime ${ }^{30}$.

De fato, a argumentação acerca da apuração dos motivos da impugnação ao lançamento tributário é significativa, uma vez que o descumprimento da obrigação tributária pode ter várias fontes, dentre as quais a ausência de recursos materiais; a exação ser inconstitucional e a ocorrência de fraude para se eximir às obrigações para com o Fisco.

O STF e o STJ vêm firmando tal questão e entendendo que não há justa causa para o oferecimento da denúncia quando o procedimento administrativo fiscal estiver fluindo:

PENAL. PROCESSUAL PENAL. CRIME CONTRA A ORDEM TRIBUTÁRIA. Lei 8.137/90, art. 10. LANÇAMENTO FISCAL: CONSTITUIÇÃO DO CRÉDITO FISCAL.

I. - Falta justa causa para a ação penal pela prática do crime tipificado no art. 1ㅇa da Lei 8.137, de 1990, enquanto não constituído, em definitivo, o crédito fiscal pelo lançamento. É dizer, a consumação do crime tipificado no art. 10 da Lei 8.137/90 somente se verifica com a constituição do crédito fiscal, começando a correr, a partir daí, a prescrição. HC 81.611/DF, Ministro Sepúlveda Pertence, Plenário, 10.12.2003. II. - HC deferido ${ }^{31}$.

RECURSO ORDINÁRIO EM HABEAS CORPUS. PENAL E PROCESSO PENAL. CRIME CONTRA A ORDEM TRIBUTÁRIA. PROCESSO ADMINISTRATIVO FISCAL NÃO FINDADO. ARTIGO 83 DA LEI № 9.430/96. MINISTÉRIO PÚBLICO DOMINUS LITIS DA AÇÃO PENAL PÚBliCA. TIPO PENAL DO ARTIGO 10 DA LEI № 8.137/90: CRIMES DE RESULTADO. RECURSO PROVIDO.

1. A norma inserta no art. 83 da Lei no 9.430/96 é dirigida à autoridade fazendária, não ao Ministério Publico, dominus litis da ação penal pública por atribuição constitucional.

2. O procedimento administrativo-fiscal não é condição jurídica para a propositura da ação penal, nem tampouco possui o condão de restringir e/ou limitar a livre e independente atuação do Ministério Público.

3. É, contudo, condição necessária a validar justa causa para o oferecimento da ação penal, nos crimes insertos no artigo 10 da Lei no 8.137/90, a constituição definitiva do crédito pelo lançamento, eis que são crimes de resultado.

30 EISELE, Andreas. Op. cit. p. 234/235. VELLOSO. Julgamento: 07/06/2005 Órgão Julgador: Segunda Turma Publicação: DJ 01-07- 2005 PP-00087 EMENT VOL-02198-02 PP-00366 Disponível na internet em < http://gemini.stf.gov.br/cgibin/ nphbrs?d=SJUR\&n=julg\&s1=crime+contra+ordem+tribut\%E1ria\&l=20\&u=http://www.stf.gov.br/Jurispr udencia/Jurisp.asp\&Sect1=IMAGE\&Sect2=THESOFF\&Sect3=PLURON\&Sect6=SJURN\&p=1\&r=1\&f=G> Data do Acesso: 28/08/2005. 
4. Recurso provido para determinar o trancamento das ações penais nos2002.0000123-2 e 2003.0000117-8, ambas em curso na Vara Criminal da Comarca de Araucária/PR

\section{Conclusões}

O Direito Penal Tributário deve existir, com sanções sendo impostas as infrações, mas somente se adotar como bem jurídico a tutela da ordem tributária, com os valores a ela ínsitos, não considerando como instrumento de arrecadação, subvertendo a fragmentariedade e substituindo a LEF.

O intérprete da lei penal deve fazer uma conjugação dos elementos dos tipos penais com a sistemática penal, pois mediante a apuração do ilícito tributário pode se extrair a plena configuração do fato gerador, pois daí sim poderá ser apurado o ilícito penal, sob pena de violação dos axiomas nullum accusatio sine probatione e nulla probatio sine defensione.

A inexigibilidade de conduta diversa pode afastar o delito, sendo ônus de a defesa demonstrar de forma hábil sua presença, ou seja, a questão é probatória e, em prol do princípio da preservação da empresa instituído no NCC e na função social da empresa constitucionalmente prevista a excludente deve ser conhecida.

O crime continuado é plenamente possível de ocorrer em detrimento do concurso material de delitos, pois os fatos geradores acontecem periodicamente, mas para fins de arrecadação são recolhidos ao fim do ano, e, o critério de 30 dias da jurisprudência deve ser desconsiderado em prol do favor rei.

A interdependência das instâncias penal e administrativa é inegável, sendo que o procedimento administrativo fiscal é condição para o exercício da ação penal, pois quando se discute a existência e valor da exação está justamente afetando a tipicidade da conduta e a própria culpabilidade do agente, razão pela qual firmamos entendimento no qual a representação configura elemento integrante do tipo penal de sonegação fiscal.

Ao fim, lembramos que o Direito Penal Tributário deve se basear nas lições de Luigi Ferrajoli que proclama por um direito e sociedade permeados de garantias, entrelaçadas e unidas, na busca de efetividade e não desrespeito ao constitucionalismo puro:

32 BRASIL. JURISPRUDENCIA. RHC 16555/PR; RECURSO ORDINARIO EM HABEAS CORPUS 2004/0124922-3 Relator Ministro HÉLIO QUAGLIA BARBOSA (1127) Órgão Julgador: T6 - SEXTA TURMA. Data do Julgamento: 30/06/2005 Data da Publicação DJ 15.08.2005 p. 362. Data do Acesso: 28/08/2005. 
Hemos visto como el modelo penal garantista, aun cuando recibido en La Constitución iltaliana y em otras Constituciones como parâmetro de racionalidad, de justicia y de legitimidad de la intervención punitiva, se encuentra amplamente desatendido em la práctica, tanto se si considera la legislación penal ordinária como si se mira a la jurisdicción o, peor aún, a lás prácticas administrativas y policiales. Esta divergência entre la normatividad del modelo en el nível constitucional y su ausência de efectividad en los niveles inferiores comporta El riesgo de hacer de aquél uma simple fachada, com meras funciones de mistificación ideológica del conjunto. La orrrientación que desde hace algún tiempo se conoce por el nombre de "garantismo" nació em el campo penal como uma réplica al creciente desarollo de la citada divergência, así como a lãs culturas jurídicas y políticas que la han avalado, ocultado y alimentado, casi siempre em nombre de la defensa del estado del derecho y del ordenamento democrrático ${ }^{33}$

\section{Referências}

AMARO, Luciano. Direito Tributário Brasileiro. 9. ed. São Paulo: Saraiva, 2003.

BASTOS, Marcelo Lessa. Investigação nos Crimes de Ação Penal de Iniciativa Pública: Papel do Ministério Público. Uma Abordagem à Luz do Sistema Acusatório e do Garantismo. Rio de Janeiro: Lúmen Júris, 2004.

CALLEGARI, André Luís. Imputação Objetiva no Direito Penal. Revista Brasileira de Ciências Criminais - IBCCrim, São Paulo, v. 8, n. 30, abr./jun. 2000.

CAMARGO, Antônio Luís Chaves de. Imputação Objetiva e Direito Penal Brasileiro. São Paulo: Livraria Cultural, 2001.

DA ROSA, Fábio Bittencourt. Legitimação do Ato de Criminalizar. Porto Alegre: Livraria do Advogado, 2001.

EISELE, Andreas. Crimes contra a Ordem Tributária. 2. ed. São Paulo: Dialética. 2002.

ESTELLITA, Heloísa. Pagamento e Parcelamento Nos Crimes Tributários: A nova disciplina da Lei 10.684/03. Boletim do IBCCRIM, Setembro. São Paulo: Revista dos Tribunais, 2003.

FERRAJOLI. Luigi. Derecho y Razón: Teoría del Garantismo Penal. 5. ed. Madrid: Editorial Trotta, 2001.

LOPES, Rodrigo Fernando de Freitas. Crime de Sonegação Fiscal: a crise do Estado como causa de exclusão da culpabilidade. Curitiba: Juruá, 2002.

33 FERRAJOLI, Luigi. Op. cit. p. 851. 
LOTT, Herman. Crimes contra a ordem tributária. Jus Navigandi, Teresina, v. 6, n. 58, ago. 2002. Disponível em: <http://jus2.uol.com.br/doutrina/texto.asp?id=3054>.

MIRABETE, Julio Fabbrini. Processo Penal. 16. ed. São Paulo: Atlas, 2004.

MORAES, Alexandre de, et al. Legislação Penal Especial. 5. ed. São Paulo: Atlas, 2002.

NUCCl, Guilherme de Souza. Código Penal Comentado. 2. ed. São Paulo: Revista dos Tribunais, 2002.

NABARRETE NETO, André. Extinção da Punibilidade nos Crimes contra a Ordem Tributária. RBCcrim, São Paulo, v. 5, n. 17, jan./mar. 1997.

PRADO, Luiz Régis. Elementos de Direito Penal. 3. ed. São Paulo: Revista dos Tribunais, 2005. V. 1.

. Curso de Direito Penal Brasileiro. São Paulo: Revista dos Tribunais, 1999. v. 1.

ROCHA, Fernando A.N. Galvão da. Imputação Objetiva nos crimes omissivos. Revista Âmbito Jurídico, n. 3, mar. 2001. Disponível em: <www.ambitojuridico.com.br>.

SILVA, José Afonso da. Curso de Direito Constitucional Positivo. 18. ed. São Paulo: Malheiros, 2000.

SMANIO, Gianpaolo Poggio et al. Legislação Penal Especial. 5. ed. São Paulo: Atlas, 2002.

SILVA, Aloísio Firmo Guimarães da. Crimes tributários e condição objetiva de punibilidade. Jus Navigandi, Teresina, v. 8, n. 183, 5 jan. 2004. Disponível em:

<http://jus2.uol.com.br/doutrina/texto.asp?id=4636>.

TEIXEIRA, Fernando Tadeu Cabral. O parcelamento do débito tributário como causa extintiva da punibilidade - artigo 34, da Lei 9.249/95. Disponível em:<http://www.ibccrim.org.br>.

TEOTÔNIO, Luís Augusto Freire. Culpabilidade: concepções modernas, tendências internacionais e nacionais. Campinas: Minelli, 2002. 
Revista de Direito Público, LondRina, V. 1, N. 1, P. 13-36, JAN./ABR. 2006. 